\title{
Te Deum laudamus!
}

Kolejny numer „Pro Musica Sacra” wychodzi w szczególnym roku dla naszego Instytutu. To właśnie z inspiracji Międzyuczelnianego Instytutu Muzyki Kościelnej w Krakowie papież emeryt Benedykt XVI otrzymuje doktoraty honoris causa Akademii Muzycznej w Krakowie i Uniwersytetu Papieskiego Jana Pawła II w Krakowie. Dlatego wszyscy, którzy tworzymy tę jednostkę naukowo-dydaktyczną, chcemy razem śpiewać uroczyste Te Deum laudamus!

W tym roczniku naszego czasopisma znajdują się artykuły o teologicznym znaczeniu muzyki kościelnej oraz sprawozdanie z uroczystości wręczenia doktoratów honoris causa. Jednak już teraz wydaje się słuszne przypomnienie dwóch ważnych listów, które dotyczą owego wyróżnienia. 1 stycznia 2015 roku rektorzy Akademii Muzycznej w Krakowie i Uniwersytetu Papieskiego Jana Pawła II w Krakowie w liście do papieża emeryt Benedykta XVI napisali:

\begin{abstract}
Międzyuczelniany Instytut Muzyki Kościelnej w Krakowie, działający przy obu uczelniach, wystąpił do nas z zapytaniem o możliwość nadania Waszej Świątobliwości doktoratu honoris causa dwóch uczelni: Akademii Muzycznej w Krakowie i Uniwersytetu Papieskiego Jana Pawła II w Krakowie równocześnie. Obaj jesteśmy przekonani do tego z całego serca. Byłby to dla nas wielki zaszczyt i spłacenie długu w stosunku do Waszej Świątobliwości, a zarazem możliwość ofiarowania tego, co uczelnie posiadają najcenniejszego dla Osoby, której w dziedzinie muzyki kościelnej zawdzięczamy tak wiele ${ }^{1}$.
\end{abstract}

Ojciec święty emeryt Benedykt XVI, odpowiadając rektorom na ich propozycję przyznania doktoratu honoris causa, napisał:

\footnotetext{
1 List rektorów Akademii Muzycznej w Krakowie i Uniwersytetu Papieskiego Jana Pawła II w Krakowie do Ojca Świętego emeryta Benedykta XVI z dnia 1 stycznia 2015 roku, Archiwum Międzyuczelnianego Instytutu Muzyki Kościelnej w Krakowie.
} 
kiedy wszedłem w klimat ciszy i ukrycia, jaki wypadało przyjąć papieżowi emerytowi, zdecydowałem nie przyjmować w przyszłości żadnych wyróżnień i innych podobnych rzeczy. Jednak propozycja przedstawiona mi przez Akademię Muzyczną w Krakowie i Uniwersytet Papieski Jana Pawła II w Krakowie to prawdziwy wyjątek. Jestem świadomy, że moje niewielkie teksty o muzyce kościelnej nie zasługują na takie wyróżnienie. Jednak radość, że mogę w ten sposób na nowo stanąć blisko czcigodnej i umiłowanej osoby świętego Jana Pawła II, jest tak wielka, że nie mogę powiedzieć „nie” w sprawie tego wyróżnienia. Przyjmuję zatem z wdzięcznością i radością doktorat honoris causa ze strony Waszych szanownych Instytucji ${ }^{2}$.

W 6-letniej historii Międzyuczelnianego Instytutu Muzyki Kościelnej, ale myślę, że także w historii struktur, w ramach których od lat 70. XX wieku tworzyliśmy Instytut, a więc Sekcji Muzyki Liturgicznej Instytutu Liturgicznego Papieskiej Akademii Teologicznej w Krakowie, a także specjalności muzyka kościelna w Akademii Muzycznej w Krakowie od 1997 roku, nie było i nie będzie większego wydarzenia tak ważnego dla nas. Bogu za nie niech będą dzięki!

Wszystkie zamieszczone w naszym tegorocznym numerze artykuły są owocem działalności i współpracy Międzyuczelnianego Instytutu Muzyki Kościelnej w Krakowie z ośrodkami muzycznymi w Polsce i za granicą, dlatego też wszystkim należą się szczególne podziękowania. Dziękuję autorom artykułów i recenzentom, dziękuję radzie naukowej i redakcji, zwłaszcza dziękuję sekretarzowi za wielki trud zbierania w całość tego numeru i pracę dla naszego czasopisma, dziękuję Wydawnictwu Uniwersytetu Papieskiego Jana Pawła II za wspaniałą współpracę. To jest nasze wspólne dzieło.

Zachęcam tym samym wszystkich naszych czytelników do zapoznania się z ciekawymi artykułami, a także do przekazywania innym tego wyjątkowego numeru, bo dedykowanego szczególnemu patronowi wszelkich dzieł w dziedzinie muzyki kościelnej, jakim jest papież emeryt Benedykt XVI. Jego zaś pokornie proszę o przyjęcie tego naszego wspólnego dzieła, które Jemu w tym roku dedykujemy.

ks. dr hab. Robert Tyrała

Redaktor naczelny „Pro Musica Sacra”

8 czerwca 2015 roku, św. Jadwigi Królowej

2 Benedykt XVI, List do rektorów Akademii Muzycznej w Krakowie i Uniwersytetu Papieskiego Jana Pawła II w Krakowie, Rzym 5 lutego 2015 roku, Archiwum Międzyuczelnianego Instytutu Muzyki Kościelnej w Krakowie. 